\title{
The Meanings of Pregnancy in Adolescence for Young People without a History of Pregnancies
}

\author{
Paula Orchiucci Miura ${ }^{1}$ \\ Kedma Augusto Martiniano Santos ${ }^{1}$ \\ Ellen Borges Tenorio Galdino ${ }^{1}$ \\ Estefane Firmino de Oliveira Lima ${ }^{1}$ \\ Maria Marques Marinho Peronico Pedrosa ${ }^{1}$
}

\begin{abstract}
In the academic literature there is lack of studies on teenage pregnancy in young people who have not experienced pregnancy. This article aimed to investigate and analyze the meanings of teenage pregnancy for adolescents without a gestation history. The participants were 37 adolescents with no pregnancy history ( 22 males and 15 females), aged between 12 and 18 years old. The thematic design-story procedure was used as instrument, in which the young individuals were asked to draw "a pregnant adolescent in their Community". To systematize the data, Bardin's content analysis was used. Thirteen themes were observed, the most frequent being related to families, relationships and/or friends and very early pregnancies, showing the relevance of these themes for adolescents. It is concluded that teenage pregnancy, in its majority, was seen as disadvantageous, but also as desired by some young individuals, pointing to the ambiguity of the phenomenon.
\end{abstract}

Keywords: adolescents, adolescent pregnancy, meaning

\section{Os Significados da Gravidez na Adolescência para Jovens sem Histórico de Gestação}

\begin{abstract}
Resumo: Na literatura acadêmica, são escassos os estudos sobre gravidez na adolescência em jovens que não vivenciaram a gestação. Este artigo teve como objetivo investigar e analisar os significados da gravidez na adolescência para adolescentes sem histórico de gestação. Participaram 37 adolescentes sem histórico de gravidez ( 22 homens e 15 mulheres) entre 12 e 18 anos. Foi utilizado como instrumento o procedimento desenho-estória temático, tendo sido solicitado que os jovens desenhassem "uma adolescente grávida na sua comunidade". Para sistematização dos dados, utilizou-se a análise de conteúdo de Bardin. Observaram-se 13 temas, sendo os mais frequentes relacionados às famílias, às relações amorosas e/ou amizades e à gravidez muito cedo, demonstrando a relevância desses temas para os adolescentes. Conclui-se que a gravidez na adolescência, em sua maioria, foi vista como desvantajosa, mas também como desejada por alguns jovens, apontando para a ambiguidade do fenômeno.
\end{abstract}

Palavras-chave: adolescentes, gravidez na adolescência, significado

\section{Los Significados del Embarazo en la Adolescencia para Jóvenes sin Antecedentes de Gestación}

Resumen: En la literatura académica faltan estudios sobre el embarazo adolescente en jóvenes que todavía no lo han experimentado.
Este artículo tuvo como objetivo investigar y analizar los significados del embarazo en la adolescencia para adolescentes sin
antecedentes de gestación. Participaron 37 adolescentes sin antecedentes de embarazo ( 22 hombres y 15 mujeres $)$ de entre 12 y
18 años de edad. Se utilizó como instrumento el procedimiento dibujo-historia temático, habiéndose solicitado que los jóvenes
dibujaran "una adolescente embarazada en su comunidad". Para sistematizar los datos se utilizó el análisis de contenido de Bardin.
Se observaron 13 temas, siendo los más frecuentes los relacionados con las familias, relaciones amorosas y/o amistades y embarazo
muy temprano, lo que demuestra la relevancia de estos temas para las adolescentes. Se concluye que el embarazo adolescente, en su
mayoría, fue visto como desventajoso, pero también como deseado por algunos jóvenes, lo que apunta a la ambigüedad del fenómeno.

Palabras clave: adolescentes, embarazo en adolescência, significado

${ }^{1}$ Universidade Federal de Alagoas, Maceió-AL, Brazil

This article is the result of a Scientific Initiation (ScI) project, which was benefited from two ScI scholarships, one from the CNPq and the other from Universidade Federal de Alagoas.

Correspondence address: Paula Orchiucci Miura. Universidade Federal de Alagoas. Av. Lourival de Melo Mota Tabuleiro do Martins, Maceió-AL, Brazil. CEP 57.072-970. E-mail: paula.miura@ip.ufal.br
Adolescence is a development phase that is in the transition from childhood to adulthood, characterized by being a particular and singular period and a moment with unique configurations in the life of each individual (United Nations Population Fund [UNFPA], 2013). At this stage of life, according to Macedo, Azevedo and Castan (2012), adolescents begin to move away from their 
family relationships (endogenous relationships) in order to constitute their identity and expand their autonomy. In this way, endogenous relationships undergo changes in young individuals' investments regarding these family relationships, as the relationships with people outside the family environment, such as friends and dates, start to primarily receive greater investments from the adolescents.

Data from the UNFPA (2019) showed that, in 2019, the total world population was approximately 7.715 billion people, with nearly $24 \%$ young individuals aged 10-24 years old (1.8 billion young people). In Brazil, the number of young people represents $1 / 4$ of the country's population, totaling approximately 52.4 million individuals.

Regarding data on teenage pregnancy, according to the Information System on Live Births (Sistema de Informação sobre Nascidos Vivos, SINASC; Ministry of Health, 2019), in 2015 the number of live births to mothers aged between 10 and 19 years old in Brazil was 547.564. The region with the highest number of children born to adolescent mothers is the Northeast (180.360, $32.94 \%$ ), followed by the Southeast $(179.377,32.76 \%)$, North $(81.887,14.96 \%)$, South $(62.482$, $11.41 \%)$ and Midwest $(43.458,7.94 \%)$ regions.

The World Health Organization (World Health Organization, 1977) considers pregnancy in adolescence as a public health problem, as it is a risk pregnancy due to the possible repercussions for maternal-fetal health, as well as regarding the psychosocial harms. Also in this senses, some research studies (Pires et al., 2015; Taborda, Silva, Ulbricht, \& Neves, 2014) observed that teenage pregnancy was associated with losses such as school evasion, difficulties entering the formal labor market, and subemployment. In addition to these issues, intrafamily violence was noticed in the study by Miura, Tardivo and Barrientos (2017), in which the institutionalized adolescent mothers reported the distress they experienced due to lack of family support, abandonment by their parents, and other forms of violence experienced in family relationships. In this direction, the article by Araújo, Rodrigues, Oliveira and Sousa (2016) also pointed to mothers being abandoned by their partners, when they discover that the women are pregnant.

However, other perspectives must also be mentioned, as shown by the critical literature review carried out by A.C.G. Dias and Teixeira (2010), whose results alerted both to the risks and problems associated with teenage pregnancy, as well as to the socio-cultural factors related to the desire to be a father and mother at this time of life, highlighting the positive and negative aspects of the phenomenon. In another study, conducted by Lima, Nascimento and Alchieri (2015), the authors identified pregnancy as something desired by young women, showing how teenage pregnancy can also be part of the life project of many young individuals. K. D. Santos and Motta (2014) analyzed three cases of young mothers and observed the development of motherhood as a singular meaning for these adolescents with a history of deprivations (insecure family environment, lack of access to quality education and health, financial difficulties) and a possibility for them to relive an experience of significant affection that contributes to the constitution of an authentic feeling of concern and commitment to others.

Another important aspect concerns the family and social support received during adolescence, considered essential for adolescents to experience their discoveries and desires, and to continue their maturation process (Winnicott, 1961/2005). In a situation of teenage pregnancy, these family and social supports were also perceived as fundamental in the process of motherhood development, and in resuming studies and personal life, as indicated in the study by Esteves et al. (2018).

Given the above, a high number of pregnant adolescents can be observed in Brazil, as well as various papers on the theme of pregnancy in adolescence. However, few studies were identified on the meaning of teenage pregnancy in adolescents with no history of pregnancies. One of these studies was carried out by Patias and Dias (2013), who conducted a research with pregnant and non-pregnant adolescents and observed that young pregnant women have more positive views on motherhood than young non-pregnant women. Another paper in this direction was developed by Miura et al. (2018), in which the researchers held workshops with non-pregnant adolescents on the meaning of pregnancy in adolescence and identified that it was seen as something to be avoided because it caused school evasion and bodily changes in the adolescents' life.

Therefore, it is believed that the understanding and perception of young people without a history of pregnancies with respect to teenage pregnancy is fundamental for the elaboration of public policies and the implementation of actions close to the reality of the adolescents. In order to expand research in this direction, this article aimed to investigate and analyze the meanings of teenage pregnancy for adolescents without a history of pregnancies.

\section{Method}

This is a qualitative, exploratory and descriptive research study, aiming to approach and deepen on the theme under study, as well as to observe, record and describe the researched phenomenon (Hochman, Nahas, Oliveira Filho, \& Ferreira, 2005).

\section{Participants}

The information was collected in the only public elementary (initial grades, $1^{\text {st }}$ to $5^{\text {th }}$ ) and Youth and Adult Education (Educação de Jovens e Adultos, EJA) $\left(6^{\text {th }}\right.$ to $10^{\text {th }}$ years) school, located in a neighborhood on the coast of the city of Maceió-AL. This neighborhood covers a population of approximately 5.000 inhabitants, with the main economic activities being fishing, tourism and informal trade.

Students from the last grade $\left(5^{\text {th }}\right)$ of that elementary school and those from Youth and Adult Education (EJA) $\left(6^{\text {th }}\right.$ to $10^{\text {th }}$ year) were invited to participate in this research. To compose the sample, all adolescents aged 12 to 18 years 
old with no history of pregnancies were included, and those participants who were not adolescents and/or who had a history of pregnancies were excluded.

Consequently, the study participants were 37 young individuals, $22(59,5 \%)$ male and $15(40,5 \%)$ female, all aged between 12 and 18 years old, and with no history of pregnancies. The mean age was $14,86(S D=2,03)$ years old for the boys, $13,73(S D=2,31)$ years old for the girls, and $14,41(S D=2,19)$ years old for both genders. Regarding schooling, 19 adolescents (51,3\%), aged between 12 and 14 years old, were in $5^{\text {th }}$ grade, $10(52,63 \%)$ being female and 9 (47,37\%), male; and 18 young individuals (48,7\%), aged between 15 and 18 years old, were attending EJA, $5(27,78 \%)$ being girls and 13 (72,22 \%), boys.

\section{Instruments}

Thematic drawing-and-story (Tardivo, 2007; Vaisberg, 1997). The Thematic Drawing-and-Story Procedure was used as data collection instrument, consisting of: "a research technique of social representation in several contexts, in which it is necessary to apprehend the relative unconscious of the representation itself; to identify situations of rejection and prejudice; and to create strategies to modify them" (Trinca \& Tardivo, 2010, p. 303). To identify the procedures, the participants filled in a form with the following information: name, gender, age, schooling and history of pregnancies (yes or no).

\section{Procedures}

Data collection. The thematic drawing-and-story procedure (Tardivo, 2007; Vaisberg, 1997) was applied collectively, with groups of up to five adolescents. The young individuals were asked to draw "a pregnant adolescent in their community today" and to write a story and a title referring to the drawing on the back of the sheet. Each participant wrote their own story and title. Only one adolescent did not want to write his story, his attitude being respected and accepted by the team of researchers. After making the drawings, the young individuals were asked to present the production to the group, at which time the participants reported whether or not they had experienced pregnancy in adolescence. Application was carried out by a female Psychologist professor and two Psychology students of a public school in a coastal neighborhood of the city of Maceió-AL, and lasted approximately one hour with each group.

Data analysis. For the analysis of the drawing-andstories, Trinca's recommendations (1984) were followed. In this way, the graphic and verbal expressions were analyzed in a joint manner for understanding that the statements complete the graphics and vice versa. The drawings and stories were skimmed, seeking to identify the predominant themes in each drawing-and-story, with the possibility of finding more than one theme in each of them. This procedure followed Bardin's content analysis (2011), which consisted of: (1) skimming of the drawing-and-stories; (2) selection of units of analysis guided by the research problem (what are the themes/meanings of teenage pregnancy for young people without a history of pregnancies?); and (3) categorization of the themes. Data analysis was performed, in a joint manner, by five researchers of the "Epistemology and Psychological Science" research group of the CNPQ.

\section{Ethical Considerations}

This project was approved by the Ethics Committee of Universidade Federal de Alagoas (CAAE $\mathrm{N}^{\circ}$. 55022916.0.0000.5013, Opinion $\mathrm{N}^{\mathrm{o}}$. 3,391,081). The young people were invited to participate in this study by the researchers, who timely explained the purpose of the research and provided the Free and Informed Consent Form (FICF), to be filled out by the adolescents' legal guardians, and the Assent Form (AF), to be filled out by the adolescents.

\section{Results}

A total of 13 themes were identified in the drawingsand-stories, among which endogenous and exogenous relationships presented the highest incidence values. Table 1 presents the data organized by gender, with frequency of the topics standing out.

In the Endogenous Relationships theme, the male participants (11) presented a drawing-story that contained the following: the family as welcoming pregnancy (4), an unwelcoming family (3), the mother advising to avoid pregnancy (1), a pregnant woman aggressive with another child (1), and reference to the father (1) and to the brother (1). In six productions, the female participants presented the following: the mother advising her daughter not to get pregnant at this age (1); the mother welcoming the adolescent (1); a welcoming family (1); a family sad with the abortion (1); intrafamily violence against the adolescent as a reaction to the news of the pregnancy (1) and the pregnant woman's husband being abusive (1). In general, the families were perceived both as a welcoming and protective reference and as violent and invasive in the teenage pregnancy situation.

The Exogenous Relationships theme was presented in nine productions by male participants, namely: romantic relationship (2), sexual intercourse without using a condom (1), paternal abandonment (1), pregnancy associated with the desire to have a child (1), friendship and dating (1), appreciation of the baby by the adolescent father (1) and marriage/family (1). A drawing-story referred to friendship, not associated with teenage pregnancy. In the creations of female adolescents, the exogenous relationships were addressed in four drawings-and-stories, namely: flirting and inconstancy in romantic relationships (1), dating and conflict in which the boyfriend wants abortion (1), marriage (1) and paternal abandonment (1). 
Table 1

Themes presented by the female adolescents (left) and themes presented by the male adolescents (right) according to decreasing sequence of appearance

\begin{tabular}{|c|c|c|c|}
\hline \multicolumn{4}{|c|}{ Frequency of Themes } \\
\hline \multicolumn{2}{|c|}{ Female gender } & \multicolumn{2}{|c|}{ Male gender } \\
\hline Themes & Number & Themes & Number \\
\hline "A very early" pregnancy & 7 & Endogenous relationships & 11 \\
\hline Endogenous relationships & 6 & Exogenous relationships & 9 \\
\hline Exogenous relationships & 4 & Irresponsibility & 5 \\
\hline Abortion & 4 & "A very early" pregnancy & 3 \\
\hline Social Context & 3 & Overcoming & 3 \\
\hline School & 2 & Abortion & 2 \\
\hline Idealization/Reality & 2 & Social Context & 2 \\
\hline Overcoming & 2 & Resistance & 2 \\
\hline Second pregnancy & 2 & Health & 2 \\
\hline Irresponsibility & 1 & Second pregnancy & - \\
\hline Health & 1 & Contraception/Prevention & - \\
\hline Contraception/Prevention & 1 & School & - \\
\hline Resistance & - & Idealization/Reality & - \\
\hline
\end{tabular}

Source. The authors (2019).

The most frequent theme among female participants was "A very early" pregnancy, appearing in seven drawings-andstories. In the productions, the participants highlighted the following: age of the pregnant adolescents under 15 years old (5), with one of the participants highlighting the danger of teenage pregnancy and how common it is in her context; another drawing represented the mother considering the pregnancy as "early" (1) and the word "early" was highlighted with an emphasis on the title in another drawing-story (1). In the productions by the male participants, pregnancy was considered as "early" by three adolescents, highlighting the age of the pregnant adolescents (2) and the expression "the adolescent got pregnant too early" (1).

The theme of irresponsibility was highlighted in five productions by male participants, in which irresponsibility was exclusively associated with the girl for similar reasons: not using condoms (3) and not listening to her father's advice to avoid pregnancy (2). In the only production by a female participant on this topic, the drawing-story was related to the baby becoming ill due to some food the adolescent mother ate during her pregnancy (1).

The theme of Social Context refers to the use of elements in the drawings or stories that refer to the context of the adolescents' experiences. They were identified in three drawings by female participants, which specify neighborhoods in the region (2) and teenage pregnancy as a common reality in the community (1). The two productions by male participants make references to the local nature (1) and to the adolescent's neighborhood (1).

As for the Overcoming theme, the three productions by male participants present conflicts and overcomings, respectively: (1) the daughter who falls into the river and is identified by her father as dead but, in fact, she was not dead and survived the accident; (2) an adolescent was in conflict with her pregnancy, which was overcome at the expense of religion; (3) the adolescent initially rejected the pregnancy but, due to his mother's advice and to his work, the boy started to accept the pregnancy and assumed the responsibility. Both productions by female participants showed overcoming by returning to school and church after the birth of the child (1); and the acceptance of an unexpected pregnancy (1).

Abortion was considered a way of getting rid of the problem, referring to pregnancy. In the drawings-and-stories produced by the adolescents (4), they mentioned the intake of medications or food to abort and the boyfriend's imposition to undergo an abortion. The male participants, on the other hand, represented abortion as an alternative imposed by the mother (1), as a way to get rid of the pregnancy, since it was seen as a problem (1).

The theme of Health was represented by male participants (2) through the reference to healthy eating (ensuring the baby's health) and to attending prenatal care. A female participant (1) highlighted the importance of taking care of the pregnant woman, in order to guarantee her health and the baby's health.

School, Idealization/Reality, and Second Pregnancy were themes exclusively addressed in drawings-and-stories by female participants, in two productions each. In School, while in a drawing-and-story school evasion was represented by the pregnant adolescent, who had to leave her studies to take care of her child, the other showed the return to school after the child's birth. In Idealization/Reality, in the two drawings-and-stories, something beautiful and good about pregnancy was idealized, and then the reality of this situation stood out, along with its implications. In Second Pregnancy, in the first drawing-and-story, the adolescent was already a mother and was pregnant for the second time; and the second drawing-and-story presented an adolescent in her second pregnancy, the first being when she was 11 years old; however, she lost the baby in this first pregnancy. 
The theme of Resistance was expressed by two male participants because they did not want to write the story (1) and presented contents unrelated to teenage pregnancy (1). The theme of Contraceptives/Prevention appeared only once, in a production by a female participant. The drawingstory addressed calls for the use of contraceptives as a way to prevent pregnancy.

\section{Discussion}

The data from this study on schooling showed that half of the adolescents participating in this research attend Youth and Adult Education (EJA), showing that the lives of the these young individuals at school suffered interruptions in their process. And the other half, $5^{\text {th }}$ grade adolescents, presented age-grade distortion, that is, when the student is older than the recommended age for the grade, 6 years old being the age considered ideal for entering $1^{\text {st }}$ grade of elementary school (Instituto Nacional de Estudos e Pesquisas Educacionais Anisio Teixeira [INEP], 2020).

In addition to that, another situation identified in this research was the difficulty for the neighborhood's residents to access Elementary II schools and high schools, as they need to move to other neighborhoods to continue their studies. These data point in a way to the mishaps experienced by the young individuals in their schooling process, to the difficulties in the process of continuing education but, at the same time, to the presence of these young people in the school environment, considering that this research was carried out in the school.

It is important to reflect that this reality permeated by difficulties and limitations can affect the education and professionalization of these young people, as well as their insertion in the labor market. This context can also enhance school dropout, which, in addition to socioeconomic difficulties, can contribute to teenage pregnancy (Pires et al., 2015). Thus, this research emphasizes the importance of investing in public policies that favor access to education, as well as that encourage young people in their schooling process.

It was also possible to observe from the data of this study that most of the participants made reference in their drawings-and-stories to love and friendship relationships, that is, exogenous relationships. In the female gender, greater presence of conflicts in love relationships was observed, in comparison to the male gender. This can demonstrate how some female adolescents may feel helpless, without support from their partners during pregnancy. Among the male adolescents, paternal abandonment was also present once, a fact which corroborates the study by Araújo et al. (2015) on the experience of young pregnant women who were abandoned by their partners.

In addition to that, the adolescents' data showed pregnancy associated with marriage and stable love bonds, and young boys also represented the desire to be a father. This information is in accordance with the research study by Lima et al. (2015), which identified teenage pregnancy as part of the youth life project, as well as with the study by A. C. Dias and Okamoto (2019) carried out with six pregnant adolescents, aged 14 to 18 years old, who related the child's birth to the feeling of security, unshakable bond and hope in the reconstruction of their childhood experiences.

Endogenous relationships, that is, family relationships, were those most represented by the young individuals. What the adolescents draw and write in their drawings-andstories reflects their experiences (Trinca \& Tardivo, 2010); in this case, with their families. It was observed that family relationships also appeared on other themes, such as: irresponsibility (the adolescent did not listen to the paternal advice to avoid pregnancy); overcoming (the mother's advice as one of the aspects related to the adolescent accepting pregnancy); the mother, considering it "A very early pregnancy"; and the theme of abortion (imposed by the mother). It was noticed that, in their singularity, each adolescent represented their family relationships according to their experience (protective, welcoming, invasive, violent...), pointing to the relevance of the family environment in the adolescent's maturation process (Winnicott, 1961/2005).

The "A very early pregnancy" theme was an expression reported by the adolescents themselves. This meaning is in line with the understanding shared by the World Health Organization, which points to the physical, psychological and social risks of becoming pregnant in adolescence (UNFPA, 2013). This meaning leads to the discussion about the right time to get pregnant, and some adolescents think it is "too early". Numerous research studies point to these risks and harms, showing a relationship between teenage pregnancy, high school evasion rates, precarious jobs and family conflicts (Dávila-Ramírez, Fajardo-Granados, Jiménez-Cruz, Florido-Pérez, \& Vergara-Castellón, 2016; Pires et al., 2015; C. C. Santos, Cremonese, Wilhelm, Castiglioni, \& Ressel, 2014; Taborda et al., 2014).

As a problem that triggers conflicts with the family and their partners, teenage pregnancy was identified in the theme of Abortion, considering termination of pregnancy as the solution to this problem. These data corroborate the study by Moraes, Toledo, David, Avelino and Campos (2017), in which the pregnant adolescents interviewed reported some reasons for attempting abortion, such as: family rejection; having more than two sexual partners; losing their virginity in a casual encounter; and having changed partners recently.

On the other hand, the theme of Health is also identified, where we notice care and affection by some adolescents in situations of pregnancy. This representation must be related to their own experiences of protection and support in their relationships, which are important conditions for the adolescent's maturation (Winnicott, 1961/2005).

The theme of Irresponsibility raised the question about the responsibility attributed to the father by society in the context of teenage pregnancy. Male adolescents consider pregnancy as an irresponsibility, blaming only the adolescent pregnant woman. In line with these data, Amaral, Santos, Paes, Dantas and Santos (2017) highlighted the blaming of women for unwanted pregnancies, as well as the fact 
that family planning programs are focused on the female population. With this, it is possible to perceive how pregnancy is also associated with motherhood, hiding, at times, the role of the father in his responsibilities regarding the situation. Trindade, Cortez, Dornelas and Santos (2019) conducted a survey on the position of the fathers, who followed-up the pregnancy of their first child, and on the support by the health professionals at this moment. The authors observed some distancing between the fathers and these professionals, as well as the need to comply with public policies aimed at men's health with a view to training and qualifying sensitive professionals to work with this population. The reflection on gender equality in the process of holding the fathers responsible for pregnancy and caring for their offspring seems to be something fundamental to be discussed with professionals and families in different sectors: education, health, and social assistance.

Regarding the theme of Social Context, the influence of the environment on the representation of the drawingsand-stories was observed. Therefore, it is thought about the importance of living in environments that offer enhancing opportunities and not degrading ones (Espinosa, 1677/1973). In the literature review on the benefits of social sports projects for children and adolescents carried out by Cortês Neto, Dantas and Maia (2015), social inclusion, positive behavior changes, filling in "free time", increased school performance, learning sports, and improving motor performance were identified as the main benefits. In the same direction, by means of the systematic review developed by Nkhoma et al. (2020), the authors observed that investing in areas such as education, health, community and economy for young people enabled the empowerment of the adolescents and the reduction in the number of pregnancies at this phase of life. It is then worth mentioning the relevance of elaborating public policies that offer young people access to quality health, education, culture, sports and social assistance programs.

In the theme of Conflicts and Overcoming, the conflict generated by teenage pregnancy was verified but, due to personal maturation or to the support from the environment (family or religion), it was possible to be overcome. For Winnicott (1961/2005), adolescents are immature and need to experience their immaturity in order to mature emotionally but, for this to happen, their family environment needs to offer support and assistance, sustaining the vulnerabilities inherent to this phase. As Winnicott points out, "while growth is in progress, responsibility has to be borne by the parental figures" (Winnicott, 1961/2005, p. 202). All the drawings-and-stories that reported conflicts also showed overcoming, pointing to personal maturation in these adolescents.

With regard to the School, it was not very present in the representations by the male adolescents and only the girls brought this subject up for discussion. Although the school was underrepresented, it was in the school environment that this research took place. Considering this context, the theme of School was also present in other themes and can be indirectly observed, such as, for example, in the theme of "A very early pregnancy", which is a meaning that can be linked to the discourse shared among the education professionals. It is worth noting that the educational space was very important for the development of this research and can also be an environment for countless other papers that offer possibilities and potential for young people (Nkhoma et al., 2020).

The experience report by Miura et al. (2018) showed the school as a potential space for carrying out workshops that focused on the themes of adolescence, teenage pregnancy, sexual abuse and bullying. However, sex education in the schools was not identified in the systematic review by Furlanetto, Lauermann, Costa and Marin (2018) as a present and continuous work, as recommended by the National Curricular Parameters. In addition to that, the authors also point to the importance of advancing the discussion on this topic and of investing in the training of the teachers in order to "transform discriminatory sexual patterns and promote a culture of health prevention in the school environment" (Furlanetto et al., 2018, p. 550).

As for what was represented by the girls about the School (evasion by the pregnant adolescent and her return after the child's birth), a number of research studies point to more adolescents who drop out school than those who return after the child's birth (Dávila-Ramírez et al., 2016), with evasion being one of the reasons why there is recurrence of pregnancy, which is a very common practice. In a survey conducted in the city of Teresina-PI, $25,9 \%$ of the female adolescents living in the capital and $35,4 \%$ in the inland had their second pregnancy while still in their teens (Nery et al., 2015).

Contraception as Prevention was seldom mentioned. The study by Vieira, Bousquat, Barros and Alves (2017) showed that $1 / 3$ of the female adolescents used some contraceptive method when they got pregnant, although with several and evident reports of irregular use. Among them, $70,3 \%$ used hormonal contraceptive methods, $28,4 \%$ used male condoms, and $1,4 \%$ used both methods combined. The morning-after pill was known by $67,5 \%$ of the young women and was used by $33,5 \%$ of these. Nkhoma et al. (2020) showed that educational policies together with accessibility to contraceptives helped to reduce the number of unwanted pregnancies in the United States, which points to the importance of sex education in schools.

Finally, this research sought to investigate and analyze the meaning of teenage pregnancy for adolescents aged between 12 and 18 years old without a history of pregnancies. Through drawings-and-stories with themes created by 37 participants (22 male and 15 female), it was possible to perceive the diversity of themes reported by the young individuals.

Teenage pregnancy was represented by the adolescents through numerous themes, with the highest incidence related to Endogenous and Exogenous Relationships, showing the importance of family relationships in the event of pregnancy, as well as love relationships and friendships, which are so relevant for the adolescents. Other themes were also reported, such as "A very early" pregnancy, more expressive among 
the female adolescents, which shows the notion of pregnancy in this stage of life as precocious, as well as an event that involves challenges and responsibilities, which is a theme that can be present due to the shared and accepted discourse of the education professionals.

This research also pointed to the low appearance of the theme of Contraceptives/Prevention, raising the question about why this theme is not present in a meaningful way in the lives of these young individuals. Future studies could contribute to these questions. Another issue that deserves to be further explored in future research studies is the accountability of pregnancy attributed to women.

Regarding the limitations of this study, all the participants attended public schools, reason why it would be interesting to expand this research to private schools. Another suggestion would be conducting studies with participants with and without a history of pregnancies, in order to compare the data. In addition, this was a cross-sectional survey, which made it impossible to know the meanings of teenage pregnancy for young people participating in this study at other times in their lives.

In view of the above, it was possible to perceive that teenage pregnancy, for the most part, was represented by young people with no history of pregnancies as unfavorable at this stage of life, but young individuals were also observed with the desire to have children, to constitute their family and to get married, pointing to the ambiguity of the phenomenon. In this context, this research suggests the elaboration of public policies that reflect on and consider some elements highlighted in this study, such as the singularity of each adolescent; the family, social and cultural environment of the young individuals; school and health as potential spaces for discussing this theme; the importance of education and training on the subject matter by professionals in education, health and social assistance, among other areas; the implementation of social projects that offer opportunities for young people; and the enhancement of access to quality health, education and culture for children, adolescents and their families.

\section{References}

Amaral, A. M. S., Santos, D., Paes, H. C. S., Dantas, I. S., \& Santos, D. S. S. (2017). Adolescência, gênero e sexualidade: Uma revisão integrativa [Adolescence, gender and sexuality: An integrative review]. Revista Enfermagem Contemporânea, 6(1), 62-67. doi:10.17267/2317-3378rec.v6i1.1114

Araújo, R. L. D., Nóbrega, A. L., Nóbrega, J. Y. L., Silva, G. S., Sousa, K. M. O., Coelho, D. C., \& Silva, A. P. (2015). Gravidez na adolescência: Consequências voltadas para a mulher [Pregnancy in adolescence: Consequences for women focused]. Informativo Técnico do Semiárido, 9(1), 15-22. Retrieved from https://www.gvaa.com.br/ revista/index.php/INTESA/article/view/3189/2727
Araújo, R. L. D., Rodrigues, E. S. R. C., Oliveira, G. G., \& Sousa, K. M. O. (2016). Gravidez na adolescência: Consequências centralizadas para a mulher [Pregnancy in adolescence: Consequences for women focused]. Temas em Saúde, 16(2), 567-587. Retrieved from http://temasemsaude.com/ wp-content/uploads/2016/08/16231.pdf

Bardin, L. (2011). Análise de conteúdo [Content analysis] (L. A. Reto \& A. Pinheiro, Trans.). São Paulo, SP: Edições 70.

Cortês Neto, E. D., Dantas, M. M. C., \& Maia, E. M. C. (2015). Benefícios dos projetos sociais esportivos em crianças e adolescentes [The benefits of social sports projects for children and teenagers]. Saúde \& Transformação Social, 6(3), 109-117. Retrieved from http://incubadora. periodicos.ufsc.br/index.php/saudeetransformacao/ article/view/3561/4489

Dávila-Ramírez, F. A., Fajardo-Granados, D. E., JiménezCruz, C. A., Florido-Pérez, C., \& Vergara-Castellón, K. C. (2016). Factores de riesgo psicosocial para embarazo temprano y deserción escolar en mujeres adolescents [Risk psychosocial factors to school dropout and early teenage pregnancy]. Revista Ciencias de la Salud, 14(1), 93-101. doi:10.12804/revsalud14.01.2016.11

Dias, A. C., \& Okamoto, M. Y. (2019). Uma leitura psicanalítica da gravidez na adolescência [A psychoanalytic reading of teenage pregnancy]. Estudos Interdisciplinares em Psicologia, 10(1), 190-208. doi:10.5433/2236-6407.2019v10n1p190

Dias, A. C. G., \& Teixeira, M. A. P. (2010). Gravidez na adolescência: Um olhar sobre um fenômeno complexo [Adolescent pregnancy: A look at a complex phenomenon]. Paidéia (Ribeirão Preto), 20(45), 123-131. doi:10.1590/S0103-863X2010000100015

Espinosa, B. (1973). Ética. In Os pensadores [The thinkers] (M. S. Chauí, Trans.). São Paulo, SP: Editora Abril. (Original work published 1677).

Esteves, I., Bica, I., Cunha, M., Aparício, G., Ferreira, M., \& Martins M. H. (2018). A importância da resiliência e de um suporte social efetivo na vivência da gravidez e maternidade precoces [The importance of resilience and effective social support in the experience of early pregnancy and motherhood]. Revista Portuguesa de Enfermagem de Saúde Mental, (spe 6), 9-16. doi:10.19131/rpesm.0207

Furlanetto, M. F., Lauermann, F., Costa, C. B., \& Marin, A. H. (2018). Educação sexual em escolas brasileiras: Revisão sistemática da literatura [Sexual education in brazilian education: Systematic revision of the literature]. Cadernos de Pesquisa, 48(168), 550-571. doi:10.1590/198053145084

Hochman, B., Nahas, F. X., Oliveira Filho, R. S., \& Ferreira, L. M. (2005). Desenhos de pesquisa [Research designs]. Acta Cirúrgica Brasileira, 20(Suppl. 2), 2-9. doi:10.1590/ S0102-86502005000800002 
Instituto Nacional de Estudos e Pesquisas Educacionais Anísio Teixeira. (2020). Censo da educação básica 2019: Resumo técnico [Basic education census 2019: Technical summary]. Brasília, DF: INEP/MEC.

Lima, N. R. B., Nascimento, E. G. C., \& Alchieri, J. C. (2015). História de vida da mulher: Qual a verdadeira repercussão da gravidez na adolescência? [Life story of women: What is the real impact of pregnancy in adolescence?]. Adolescência \& Saúde, 12(1), 57-65. Retrieved from http://adolescenciaesaude.com/detalhe_ artigo.asp? $\mathrm{id}=476$

Macedo, M. M. K., Azevedo, B. H., \& Castan, J. U. (2012). Adolescência e psicanálise [Adolescence and psychoanalysis]. In M. M. K. Macedo (Org.), Adolescência e psicanálise: Intersecções possíveis [Adolescence and psychoanalysis: Possible intersections] (2nd ed., pp. 15-54). Porto Alegre, RS: EdiPUCRS.

Ministério da Saúde. DATASUS. (2019). SINASCSistema de informações de nascidos vivos [Live birth information system]. Brasília, DF: Autor. Retrieved from http://www2.datasus.gov.br/DATASUS/index. php .area $=0205 \& \mathrm{id}=6936 \& \mathrm{VObj}=\mathrm{http}: / /$ tabnet .datasus. gov.br/cgi/deftohtm.exe?sinasc/cnv/nv

Miura, P. O., Oliveira, A. S., Galdino, E. T., Santos, K. A. M., Costa, M. L., \& Costa, G. C. (2018). O ambiente escolar como espaço potencial para adolescente: Relato de experiência [The school environment as potential space for adolescents: Report of experience]. Pesquisas e Práticas Psicossociais, 13(2), 1-14. Retrieved from http://www.seer.ufsj.edu.br/index.php/revista_ppp/ article/view/2523

Miura, P. O., Tardivo, L. S. L. P. C., \& Barrientos, D. M. S. (2017). O sofrimento psíquico das mães adolescentes acolhidas institucionalmente [The psychic suffering of institutionally sheltered adolescent mothers]. Revista Latinoamericana de Psicopatologia Fundamental, 20(2), 331-348. doi:10.1590/1415-4714.2017v20n2p331-8

Moraes, E. V., Toledo, O. R., David, F. L., Avelino, M. M., \& Campos R. N. (2017). Gravidez na adolescência e aborto: Implicações da ausência de apoio familiar [Adolescent pregnancy and abortion: Implications of absence of family support]. Adolescência \& Saúde, 14(3), 16-23. Retrieved from $\mathrm{http}: / /$ adolescenciaesaude.com/detalhe_artigo.asp? $\mathrm{id}=667$

Nery, I. S., Gomes, K. R. O., Barros, I. C., Gomes, I. S., Fernandes, A. C. N., \& Viana, L. M. M. (2015). Fatores associados à reincidência de gravidez após gestação na adolescência no Piauí, Brasil [Factors associated with recurrent pregnancy following initial teenage pregnancy in Piauí, Brazil]. Epidemiologia e Serviços de Saúde, 24(4), 671-680. doi:10.5123/S1679-49742015000400009
Nkhoma, D. E., Lin, C. P., Katengeza, H. L., Soko, C. J., Estinfort, W., Wang, Y. C., ... Iqbal, U. (2020). Girls' empowerment and adolescent pregnancy: A systematic review. International Journal of Environmental Research and Public Health, 17(5), 1664. doi:10.3390/ ijerph17051664

Organización Mundial de la Salud. (1977). Necesidades de salud de los adolescentes: Informe de un Comité de expertos de la OMS [Health needs of adolescentes: Report of a Committee of Experts of the WHO]. Ginebra, Suiza: Autor. Retrieved from https://apps.who.int/iris/ bitstream/handle/10665/41156/WHO TRS 609 spa. pdf? sequence $=1 \&$ isAllowed $=\mathrm{y}$

Patias, N. D., \& Dias, A. C. G. (2013). Opiniões sobre maternidade em adolescentes grávidas e não-grávidas [Opinions about maternity among pregnant teens and non-pregnant teens]. Arquivos Brasileiros de Psicologia, 65(1), 88-102. Retrieved from http://pepsic. bvsalud.org/scielo.php?script $=$ sci_arttext\&pid $=$ S1809. $52672013000100007 \& \operatorname{lng}=\mathrm{en} \& \operatorname{tlng}=\mathrm{pt}$

Pires, R., Pereira, J., Pedrosa, A. A., Vilar, D., Vicente, L., \& Canavarro, M. C. (2015). Contributo de fatores individuais, sociais e ambientais para a decisão de prosseguir uma gravidez não planeada na adolescência: Um estudo caracterizador da realidade portuguesa [Contribution of individual, social and environmental factors to the decision to pursue an unplanned pregnancy in adolescence: A study that characterizes the portuguese reality]. Análise Psicológica, 33(1), 19-38. Retrieved from https://eg.uc.pt/bitstream/10316/47009/1/ PiresEtAl_2015_An\%c3\%a1lisePsicol\%c3\%b3gica EG_UC.pdf

Santos, C. C., Cremonese, L., Wilhelm, L. A., Castiglioni, C. M., \& Ressel, L. B. (2014). Perfil social de adolescentes gestantes e abandono escolar [Social profile of pregnant adolescents and school evasion]. Adolescência \& Saúde, 11(3), 71-76. Retrieved from https://cdn.publisher.gn1. link/adolescenciaesaude.com/pdf/v11n3a08.pdf

Santos, K. D., \& Motta, I. F. (2014). O significado da maternidade na trajetória de três jovens mães: Um estudo psicanalítico [The meaning of motherhood for three young mothers: A psychoanalytic study]. Estudos de Psicologia (Campinas), 31(4), 517-525. doi:10.1590/0103-166X2014000400006

Taborda, J. A., Silva, F. C., Ulbricht, L., \& Neves, E. B. (2014). Consequências da gravidez na adolescência para as meninas considerando-se as diferenças socioeconômicas entre elas [Consequences of teenage pregnancy for girls considering the socioeconomic differences between them]. Cadernos Saude Coletiva, 22(1), 16-24. doi:10.1590/1414-462X201400010004

Tardivo, L. S. L. P. C. (2007). O adolescente e sofrimento emocional nos dias de hoje [The teenager and emotional distress these days]. São Paulo, SP: Vetor. 
Trinca, W. (1984). Diagnóstico psicológico: A prática clínica [Psychological diagnosis: Clinical practice]. São Paulo, SP: EPU.

Trinca, W., \& Tardivo, L. S. L.P.C. (2010). Desenvolvimentos do procedimento de desenhos-estórias (D-E). In J. A. Cunha, Psicodiagnósticos- $V$ [Psychodiagnostics-V] (pp. 429-438). Porto Alegre, RS: Artes Médicas.

Trindade, Z., Cortez, M. B., Dornelas, K., \& Santos, M. (2019). First-time fathers: Demand for support and visibility. Saúde e Sociedade, 28(1), 250-261. doi:10.1590/s0104-12902019170892

United Nations Population Fund. (2013). Adolescent pregnancy: A review of the evidence population and development. New York, NY: UNFPA. Retrieved from http://www.unfpa.org/sites/default/files/pub-pdf/ ADOLESCENT\%20PREGNANCY_UNFPA.pdf

United Nations Population Fund. (2019). World population dashboard. Retrieved from https://www.unfpa.org/data/ world-population/BR

Vaisberg, T. M. J.A. (1997). Investigação de representações sociais. In W. Trinca (Org.), Formas de investigação clínica em psicologia: O procedimento de desenhosestórias e desenhos de famílias com estórias [Forms of clinical research in psychology: The procedure of story telling and story telling] (pp. 255-288). São Paulo, SP: Vetor.

Vieira, E. M., Bousquat, A., Barros, C. R. S., \& Alves, M. C. G. P. (2017). Adolescent pregnancy and transition to adulthood in young users of the SUS. Revista de Saúde Pública, 51, 25. doi:10.1590/S15188787.2017051006528

Winnicott, D. W. (2005). Adolescência: Transpondo a zona das calmarias. In A família e o desenvolvimento individual [The family and individual development] (M. B. Cipolla, Trans., 3rd ed., pp. 115-127). São Paulo, SP: Martins Fontes. (Original work published 1961).
Paula Orchiucci Miura is a Professor of the Institute of Psychology at Universidade Federal de Alagoas, MaceióAL, Brazil.

Kedma Augusto Martiniano Santos is a master's student of the Postgraduate Program of the Institute of Psychology at Universidade Federal de Alagoas, Maceió-AL, Brazil.

Ellen Borges Tenorio Galdino is graduate in Psychology at Universidade Federal de Alagoas, Maceió-AL, Brazil.

Estefane Firmino de Oliveira Lima is a Psychologist at the Program of Multi-Professional Residency in Adult and Older Adult Health, Maceió-AL, Brazil.

Maria Marques Marinho Peronico Pedrosa is a master's student of the Postgraduate Program at the Institute of Psychology at Universidade Federal de Alagoas, Maceió-AL, Brazil.

\section{Authors' Contribution:}

All the authors made substantial contributions to the conception and design of this study, to data analysis and interpretation, and to the manuscript review and approval of the final version. All the authors assume public responsibility for content of the manuscript.

Associate editor:

Adriana Martins Saur

Received: Oct. 31, 2019

1st Revision: Mar. 22, 2020

2nd Revision: Oct. 10, 2020

3rd Revision: Dec. 14, 2020

4th Revision: Feb. 16, 2021

Approved: Feb. 18, 2021

How to cite this article:

Miura, P. O., Santos, K. A. M., Galdino, E. B. T., Lima, E. F. O., \& Pedrosa, M. M. M. P. (2021). The Meanings of Pregnancy in Adolescence for Young People without a History of Pregnancies. Paidéia (Ribeirão Preto), 31, e3114.doi:https://doi.org/10.1590/1982-4327e3114 